\title{
THE EFFECT OF THE LOST TWIN GAME ON STUDENTS' PRONUNCIATION PERFORMANCE
}

\author{
Rabi'ah*, Achmad Baidawi, Wahab Syakhirul Alim \\ State Islamic Institute of Madura, Indonesia \\ (robiah_43@yahoo.com)
}

Received: $20^{\text {th }}$ March 2020; Revised: $17^{\text {th }}$ May 2020; Accepted: $28^{\text {th }}$ June 2020

\begin{abstract}
The objective of this study was to examine whether the use of the Lost Twin Game in teaching pronunciation affects students' pronunciation and how significant the effect is on their pronunciation performance. This research was motivated by the phenomenon that there are various obstacles to teaching pronunciation at the school level including those related to students' personal characteristics and teachers' instructional methods. The participants of this study were eighth grade students of MTs Nasrul Ulum Bagandan Pamekasan, consisting of 20 students. This research is pre-experimental utilizing a pretest and posttest, and the data for this study were analyzed statistically using a t-test with SPSS 20. The results of this study show that the $t$-value 0.000 is lower than 0.05 which means that there is a significant effect of the treatment on the students' pronunciation performance, and the treatment also accounts for the students' score increase by about $25 \%$. It is, thus, concluded that the incorporation of the Lost Twin Game in teaching pronunciation is effective in improving students' pronunciation performance.
\end{abstract}

Key Words: effect; Lost Twin Game; students' pronunciation performance

\section{ABSTRAK}

Tujuan dari penelitian ini adalah untuk menguji apakah penggunaan Lost Twin Game dalam pengajaran pelafalan mempengaruhi pelafalan siswa dan seberapa signifikan pengaruhnya terhadap kinerja pelafalan mereka. Penelitian ini dilatarbelakangi oleh fenomena adanya berbagai kendala dalam pembelajaran pengucapan di tingkat sekolah termasuk yang berkaitan dengan karakteristik pribadi siswa dan metode pembelajaran guru. Partisipan dalam penelitian ini adalah siswa kelas VIII MTs Nasrul Ulum Bagandan Pamekasan yang berjumlah 20 orang. Penelitian ini merupakan penelitian praeksperimental dengan menggunakan pretest dan posttest, dan data untuk penelitian ini dianalisis secara statistik menggunakan uji-t dengan SPSS 20. Hasil penelitian ini menunjukkan bahwa t-value 0,000 lebih kecil dari 0,05 yang berarti ada pengaruh yang signifikan dari perlakuan terhadap kinerja pengucapan siswa, dan perlakuan tersebut juga menyebabkan peningkatan nilai siswa sekitar 25\%. Dengan demikian, disimpulkan bahwa penggunaan Lost Twin Game dalam pengajaran pengucapan efektif dalam meningkatkan kinerja pengucapan siswa.

Kata Kunci: dampak; Lost Twin Game; kinerja pengucapan siswa

How to Cite: Rabi'ah, Baidawi, A., Alim, W. S. (2020). The Effect of the Lost Twin Game on Students' Pronunciation Performance. IJEE (Indonesian Journal of English Education), 7(1), 63-73. doi:10.15408/ijee.v7i1.16995

*Corresponding author

IJEE (Indonesian Journal of English Education), 7 (1), 2020, 63-71

P-ISSN: 2356-1777, E-ISSN: 2443-0390 | DOI: http://doi.org/10.15408/ijee.v7i1.16995

This is an open access article under CC-BY-SA license (https://creativecommons.org/licenses/by-sa/4.0/) 


\section{INTRODUCTION}

In the teaching and learning process in the classroom, teachers usually focus on teaching English skills, namely writing, reading, speaking, and listening. They often give a little portion of teaching pronunciation. Indeed, they do not give much chance to the learners in learning pronunciation, because they do not have adequate knowledge and capacity of teaching pronunciation. In line with this case, Harmer (2007) states that many teachers do not pay enough attention to English pronunciation. One of the reasons is that they are not aware of explicit instruction or teaching techniques for pronunciation. In English books of junior and senior high schools, we often find that instruction for pronunciation skill only has a little portion. It just focuses on giving some words provided with phonetic transcriptions.

As stated earlier, pronunciation is one of the linguistic aspects less emphasized by the teachers in the classroom. It consequently leads to the fact that the students are low in their pronunciation ability. One of the reasons why the teachers seldom teach pronunciation is that they do not have various and relevant techniques for teaching pronunciation. Meanwhile, to make teaching and learning run well, classroom teachers need to make some efforts to solve the problems. One way to overcome the problems is to apply relevant and effective teaching techniques such as games, video presentation, and others. Hidayatullah (2018) states that the teacher plays a very active role in finding techniques and media that can be applied in the classroom to enhance students' pronunciation skills in a way that is not boring to them. The use of appropriate methods for suitable material will make it easier for students to understand the material being taught.

Moreover, the instructional material of pronunciation needs to be taught in various ways to make students interested in learning and get as much knowledge and skills as possible. Improving students' pronunciation ability is indeed one of the teachers' duties. According to Fraser (2000), teachers should be provided with courses and materials that help them to improve their pronunciation instruction.

Correspondingly, Harmer (2007) stated that the lack of quality, appropriate teaching and learning materials, and the lack of time to practice pronunciation are the main reasons why teachers do not pay enough attention to English pronunciation. The teachers are used to 
teaching pronunciation by asking the learners to imitate what the teacher says. These activities make the learner feel bored in learning pronunciation. Consequently, this condition makes the learners have a little knowledge about pronunciation. This statement is also supported by the findings of a study by Gilakjani, Ahmadi, \& Ahmadi (2011). They found that in many English classrooms, the teaching of pronunciation is one of the linguistic aspects that are least paid attention or are not taught much. There are a number of potential causes which lead to students' poor pronunciation skills. One of them is teachers' inability to teach their students' pronunciation well. In other words, teachers are always expected to use effective teaching techniques including games to help them teach their students' pronunciation better.

Meanwhile, many studies have been conducted as an effort to overcome the difficulties of students in pronouncing English vocabulary, but in the reality of junior high school students in English, pronunciation has not been appropriately overcome (Sartika, 2019). Most of the studies in improving students' pronunciation are by using media. Nevertheless, in this research, the researchers investigated the issue in question focusing on the teaching technique aspect because of the unavailability of teaching media for the teachers to use in the school.

Since pronunciation is important for Indonesian learners in learning English, teachers should look for a fun technique to teach pronunciation. Applying an encouraging technique in teaching pronunciation would make learners enthusiastic in taking part in the teaching and learning process. The Lost Twin Game is one of the games that treats students in exciting conditions to learn English, especially in acquiring correct pronunciation. The Lost Twin Game offers a challenge that will encourage the students to look for the word that has a similar pronunciation. Besides, the Lost Twin Game is a kind of game that makes the teaching and learning process more attractive to students. The students feel pleased and relaxed when following pronunciation lessons.

Another reason why pronunciation is less emphasized in Indonesia is that there are many elements to the teaching of pronunciation such as sound, stress, intonation, and rhythm. Incorporating the Lost Twin Game in increasing students' pronunciation ability is one of the efforts that can be done by the teacher. Sánchez, Morfín, and Campos (2007) state that the Lost Twin Game is one of the interactive games that can be 
used in the teaching and learning process of a foreign language.

According to Wright, Betteridge, and Buckby (2006), the Lost Twin Game is a matching word pair's game which includes rhyming words, phonetic pair and phonemic script. In short, the students will suit the word that has a similar sound, which is suitable for teaching pronunciation. A previous study conducted by Rahmawati and Amri (2013) found that the Lost Twin Game created a lively and enjoyable classroom activity while learning pronunciation.

According to Otlowski (1998), pronunciation is the way of uttering a word in an accepted manner. From this definition, we can say that pronunciation is the way of saying or producing the sound correctly, whereas according to Richard (as cited in Rippell, 2012) pronunciation is the act or manner of speaking a word. Furthermore, Cook as cited in Gilakjani (2016) defined pronunciation as the production of English sounds.

Learning pronunciation is very important for students of English as a foreign language, including Indonesian learners. This is because English and Indonesian have different systems in the pronunciation of words. Accurate pronunciation is vital to good communication with others, although they are not native speakers. According to Louma (2004), pronunciation includes many features of the speech stream, such as individual sounds, pitch, volume, speed, pausing, stress, and intonation.

The different pronunciation may lead to different interpretations or meanings of the utterances. The speaker should put the features in a proper place to avoid misinterpretation by the listeners. An Indonesian English teacher, therefore, should consider this in his or her English classes. Learning pronunciation does not only make students understand and know how to produce the correct pronunciation, but also improve their speaking significantly. This is because pronunciation leads to concentrating on sound, showing where they are made in the mouth, making students aware of where words should be stressed. In many cases, Indonesian learners face difficulties to change their pronunciation ability because they are so accustomed to mispronouncing the word and they think that studying pronunciation is a boring activity.

Based on the researchers' observation in some schools, teaching pronunciation is less emphasized. The old method is used to explain the pronunciation lessons, which involves imitation drills and reading aloud. It 
often occurs in pronunciation class; the teacher only reads and then asks the students to imitate what the teacher said. Another option to present pronunciation lesson is by asking the students to read the word loudly without guidance from the teachers.

Teachers should use various methods to develop the students performance in pronunciation. One of the techniques or methods to teach pronunciation is the use of the lost twin game. The Lost Twin Game is one game that encourages students to learn pronunciation actively. Nurhayati (2015) states that gaming is an activity in which participants follow prescribed rules that differ from those of real-life as they strive to attain a challenging goal. There are some advantages of games in the teaching and learning process; (1) the game played with others involves interpersonal intelligence, (2) the game involving drawing connects with visual or spatial intelligence, (3) the game often has a hands-on element, such as cards, spinners, or pieces that connect with bodily/ kinesthetic intelligence (Altan \& Gardner, 2002). In line with this, Philips (1997) also stated that games in language classrooms help children to see learning English as an enjoyable and rewarding activity.
Playing a game in the classroom develops students' cooperation with the other students. Learning pronunciation by playing in the game will help the students memorize new sounds unconsciously. They learn it in enjoyable conditions. Games are very helpful for students in a country that English is a second or foreign language. Carrier (1980) mentions some of the advantages of games such as providing various benefits to facilitate the teaching-learning process. In other words, the teacher can utilize the game because it is one of the complementary tasks of the syllabus and with which students can further develop their learning strategies. Secondly, games are flexible, which means that they can be used to teach any aspect of language. One game can even be used to teach two or three features or language skills simultaneously. In other words, the teacher is required to be creative in presenting material in the class, especially if the material is related to foreign languages which students sometimes find it difficult to learn one of them, for example, English pronunciation material. It means that one game can be used for more than one or two linguistic aspects and skills in English. It depends on the need of the students and the situation. In this case, the Lost Twin Game can be used 
to teach not only pronunciation but also vocabulary.

Thirdly, games make lessons not monotonous and boring" because they do various class activities that help encourage students' motivation and interest in learning a foreign language. By implementing games in the teaching and learning process focusing on learning pronunciation, students will enjoy the process of getting lessons without a lot of thinking. With games, students can enjoy their learning so much and may not be aware that they are learning. Finally, the Last Twin Game can help students understand English. It means that the students learn every aspect of the language, while, at the same time, they focus their attention on playing. In other words, students produce language without worrying they are doing right or wrong; they just learn and reach learning goals easily.

Philip (as cited in Wafi, 2019) approved that playing relevant games in the class can develop students' ability to work together, to finish without being aggressive. Furthermore, Sultanova (as cited in Wafi, 2019) also outlined the benefits of using games in language learning activities: (1) the use of games can reduce anxious feelings in students while learning; (2) games are very encouraging and help students to be more active in the class to express their ideas and feelings during the learning process. With the use of games, the teacher can create various contexts in which students have to use the language to communicate, exchange information, and express their own opinion (Trang, 2015); (3) games can help students to gain new experiences in the language; (4) games can increase the shift to regular classroom activities, break the ice and introduce new ideas; (5) games can increase student retention through a relaxed atmosphere on the game; (6 ) grammar games are an excellent way to practice the language (Wafi, 2019).

The same research has already been conducted by Rahmawati and Amri (2013). They found that The Lost Twin Game is a game that can be used to improve students' pronunciation as part of speaking skills while learning English.

Based on the phenomena and the previous studies above, the researchers are interested in conducting the research, which has two main objectives. The first is whether there is any effect of The Lost Twin Game on students' pronunciation performance, and the second is how significant The Lost Twin Game is in effecting the students' pronunciation performance. 


\section{METHOD}

This study was conducted using a quantitative research method. It is a systematic study of phenomena by gathering data in the form of numbers that can be measured statistically and mathematically using computational techniques in analyzing the data (QuestionPro, 2018). In short, quantitative research is a kind of research method which collects the numeric data and analyze it by using the statistical analysis. The participants of this study were 20 students of eighth grade at MTs Nasrul Ulum Bagandan Pamekasan.

The research design of this study is experimental. Sugiyono (2006) classifies three types of experimental: preexperiment, quasi-experiment, and true experiment. In this case, the researcher used pre-experimental with one group of participants for a pretest and posttest (Seel, 2012). It means that there is no election in determining the participants because there is no access for the researchers to randomize the participants. The following pattern is the model of the pre-experimental design proposed by Sugiyono:

$$
\begin{aligned}
& 0_{1} \mathrm{X} \mathrm{O}_{2} \\
& 0_{1} \text { : pretest } \\
& \text { X: treatment } \\
& 0_{2} \text { : posttest }
\end{aligned}
$$

The primary instrument for this research is the test. A test or quiz is used to measure someone's knowledge of something to determine what he or she knows or has learned. Testing measures the level of skill or knowledge that has been reached (Differences between Testing, Assessment, and Evaluation, 2017). Related with Sugiyono's model above, the treatment is the Lost Twin Game. Before giving treatment, the pretest was conducted. After giving treatment, the posttest was given. In other words, the participants get a pretest before the teacher implement The Lost Twin Game. The research was conducted in four meetings. At the first meeting, the researcher gave the pretest. The test was a pronunciation test. In the pretest, the researcher provided 50 words, then asked the participants to pronounce the words. Each word had 2 points. If the participants could pronounce the words correctly, they got 2 points for every word. At the second meeting, the researcher gave the treatment by using The Lost Twin Game to teach pronunciation in which the teacher divided the students into pairs to make all the students take part in the activity. Here are the steps in the activity of the first treatment: 1) The researchers divided the students to become two or three groups; 2) The researchers gave each group some words that have the 
same pronunciation with other group words; 3) Then, the researchers asked each student in the group to match the word by looking for the other group which has a similar sound with his or her own. After they found his or her twin sound, they sit together and then pronounce the words together.

In the second meeting of the treatment, the researchers implemented The Lost Twin Game as follows; the researchers wrote some words on the whiteboard. Then, similar words are put in the box. The words have similar pronunciation with the words on the whiteboard. The next, the teacher asked the students to come forward to match the words on the whiteboard and words in the box.

The last activity is to ask the other students to pronounce the word together by showing the words. In the fourth meeting, the researchers conducted the posttest to measure the effect of the treatment. The test is the same pronunciation test given in the pretest.

The results of the pretest and post were analyzed using t-test in SPSS 20 to know the differences.

\section{FINDINGS AND DISCUSSION}

\section{Findings}

Table 1. Paired Samples Correlations

\begin{tabular}{lllll}
\hline & N & Correlation & Sig. \\
\hline Pair 1 $\begin{array}{c}\text { Pretest } \\
\text { Posttest }\end{array}$ & 20 & .505 & .023 \\
\end{tabular}

From the table 1 , the correlation is 0.505 , suggesting a linear regression model of $25 \%$, which means that the Lost Twin Game contributes 25\% to the improvement of students' pronunciation performance.

Table 2. Paired Samples Test

\begin{tabular}{|c|c|c|c|c|c|c|c|c|c|}
\hline & & \multicolumn{5}{|c|}{ Paired Differences } & \multirow{3}{*}{$t$} & \multirow{3}{*}{$\mathrm{df}$} & \multirow{3}{*}{$\begin{array}{l}\text { Sig. } \quad(2- \\
\text { tailed })\end{array}$} \\
\hline & & \multirow[t]{2}{*}{ Mean } & \multirow[t]{2}{*}{$\begin{array}{l}\text { Std. } \\
\text { Dev. }\end{array}$} & \multirow[t]{2}{*}{$\begin{array}{l}\text { Std. } \\
\text { Error } \\
\text { Mean }\end{array}$} & $\begin{array}{l}95 \% \\
\text { Interval } \\
\text { Difference }\end{array}$ & $\begin{array}{l}\text { Confidence } \\
\text { of the }\end{array}$ & & & \\
\hline & & & & & Lower & Upper & & & \\
\hline Pair 1 & $\begin{array}{l}\text { Pretest } \\
\text { Posttest }\end{array}$ & -10.200 & 9.105 & 2.036 & -14.461 & -5.939 & -5.010 & 19 & .000 \\
\hline
\end{tabular}


Based on the table 2, we know that there is a significant difference (twotailed at 0.000) showing that the Lost Twin Game gives effect on students' prnounciation. It means that the alternative hypothesis $(\mathrm{Ha})$ is accepted, and the null hypothesis $(\mathrm{Ho})$ is rejected.

In other words, there is a significant difference in the students pronunciation performance after getting treatment and before getting treatment. The mean score of the pretest was 64.30 while after getting treatment, the mean score increased to 74.50 as can be seen in the following table 3 .

Table 3. Paired Samples Statistics

\begin{tabular}{|c|c|c|c|c|c|}
\hline & & Mean & $\mathrm{N}$ & $\begin{array}{l}\text { Std. } \\
\text { Dev. }\end{array}$ & $\begin{array}{ll}\text { Std. } & \text { Error } \\
\text { Mean } & \end{array}$ \\
\hline \multirow[t]{2}{*}{ Pair 1} & Pretest & 64.30 & 20 & 10.367 & 2.318 \\
\hline & posttest & 74.50 & 20 & 6.924 & 1.548 \\
\hline
\end{tabular}

Thus, there is a significant effect of the use of Lost Twin Game on students' pronunciation performance. Furthermore, teaching pronunciation by using this game is effective since it can contribute up to $25 \%$ on students' pronunciation performance.

\section{Discussion}

From the point of view above, the Lost Twin Game is recommended as a classroom activity to facilitate the development of students' pronunciation ability. By applying a proper method in teaching pronunciation, the teachers can reach the goal of teaching English. The Lost Twin Game not only promotes the students' ability in pronunciation but also offers a joyful learning environment. The finding of this study supports previous research done by Rahmawati and Amri (2013) who found that The Lost Twin Game could improve students' pronunciation performance as part of speaking skill. They further explained the advantages of using The Lost Twin Game to give a variety of tools to facilitate the teachinglearning activity, to be flexible and make lesson less monotonous, to familiarize English to students and finally to stimulate students' participation and give them confidence. Moreover, the students will be confident with their performance in pronouncing English words.

In line with those advantages, the result of this study also contributes to the students' pronunciation performance. It is proven that before getting treatment, the score of the pretest is lower than the score of the posttest after getting the treatment.

\section{CONCLUSION AND SUGGESTION}

Based on the research finding, the researcher concluded some points concerning the effect of the Lost Twin Game on students' pronunciation 
ability. First, there was a significant effect of the Lost Twin Game on students pronunciation ability. It is proven by the significant increase of the mean score in the posttest. The second, the result of the $t$-test analysis showed that the score of the posttest was significantly higher than that of the pretest. Based on the description above, it could be concluded that the Lost Twin Game can improve students' pronunciation performance effectively. So, the researchers suggested that the teachers use the Lost Twin Game in teaching pronunciation. This method can make the students feel joyful, relaxed, and cheerful in the process of learning and acquiring pronunciation skill.

\section{REFERENCES}

Altan, M., \& Gardner, H. (2002). Intelligence reframed: Multiple intelligences for the 21st century. TESOL Quarterly, 35, 204. https://doi.org/10.2307/3587873

Carrier, M. (1980). Take 5: Games and activities for the language learners (2nd ed.). Nelson.

Differences between testing, assessment, and evaluation. (2017, 8 August). [Online Learning tutorials for essential college skills]. Study for Success! http:/ / tutorials.istudy.psu.edu/testi ng/testing2.html

Fraser, H. (2000). Coordinating improvements in pronunciation teaching for adult learners of English as a second language. Canberra: DETYA (ANTA Innovative Project)

Gilakjani, A. P., Ahmadi, S., \& Ahmadi, M. (2011). Why is pronunciation so difficult to learn? English Language Teaching, $\quad 4(3), \quad 74$. https://doi.org/10.5539/elt.v4n3p74

Gilakjani, A. P. (2016). English pronunciation instruction: A literature review. International Journal of Research in English Education, 1(1), 6.

Harmer, J. (2007). The practice of English language teaching ( $4^{\text {th }}$ ed.). Pearson Longman.

Hidayatullah, M. S. (2018). Improving students' pronunciation through Western movie media. Al-Lisan, 3(1), 93-111.

https://doi.org/10.30603/al.v3i1.381

Luoma, S. (2004). Assessing speaking. Cambridge University Press.

Nurhayati, D. A. W. (2015). Improving students' English pronunciation ability through Go Fish game and Maze Game. Dinamika Ilmu, 15, 19.

Otlowski, M. (1998). Pronunciation: What are the expectations? (TESL/TEFL). Retrieved 17 August 2020, from http://iteslj.org/Articles/OtlowskiPronunciation.html

Rippell, M. (2012). The "pronounce for spelling" technique. Retrieved 15 February 2020, from https:/ / blog.allaboutlearningpress.c om/pronounce-for-spelling/ 
QuestionPro. (2018). Quantitative research: Definition, methods, types and examples. Retrieved from https://www.questionpro.com/blog /quantitative-research/

Rahmawati, S., \& Amri, Z. (2013). Using the lost twin game to improve pronunciation of junior high school students. 1(2), 9.

Sánchez, M. M., Morfín, A. P., \& Campos, V. E. (2007). Interactive games in the teaching-learning process of a foreign language. Teoría Y Praxis, 3(4), 47-66. https://doi.org/10.22403/UQROOM X/TYP04/04

Sartika, D. (2019). Analysis of students' proficiency in English pronunciation using YouTube-based video media. 10.

Seel, N. M. (2012). Experimental and quasiexperimental designs for research on learning. In N. M. Seel (Ed.), Encyclopedia of the sciences of learning (pp. 1223-1229). Springer US. https:/ / doi.org/10.1007/978-1-44191428-6_716
Trang, N. T. H. (2015). Using games to improve pronunciation of the second year non-English significant students at Hanoi University of Business and Technology, Internet-zhurnal «Mir nauki» 387, 1-9.

Wafi, A. (2019). Using games to improve students' active involvement in the learning of English syntax at IAIN Madura: An autonomous learning. OKARA: Jurnal Bahasa Dan Sastra, 13(1), 107. https://doi.org/10.19105/ojbs.v13i1. 2256

Wright, A., Betteridge, D., \& Buckby, M. (2006). Games for language learning. Cambridge: Cambridge University Press. 